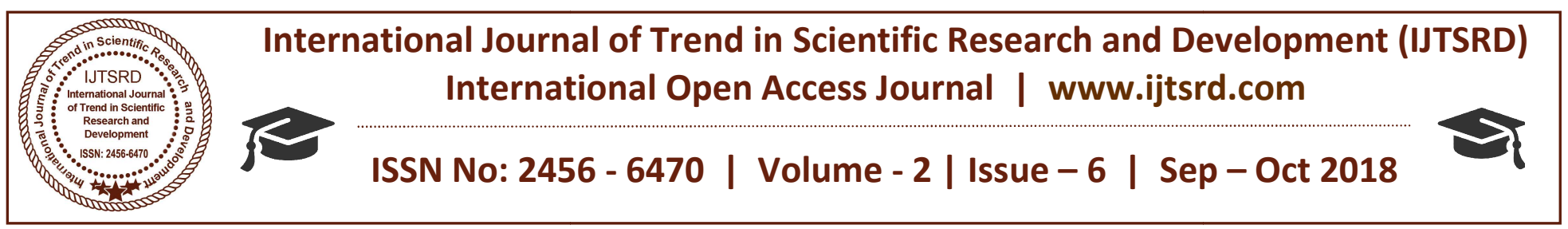

\title{
Study on Building Structures with Sloping Ground under Seismic \& Wind Load Conditions
}

\author{
Abhishek Kumar ${ }^{1}$, Pratiksha Malviya ${ }^{2}$ \\ ${ }^{1}$ M.Tech Scholar, ${ }^{2}$ Professor, \\ Department of Civil Engineering, Millennium Institute of Technology \& Science, \\ Bhopal, Madhya Pradesh, India
}

\begin{abstract}
Analysis and design of space building frame for seismic loading and wind pressure is very essential these days because construction of high rise buildings. It is also necessary to construct an economic and more durable structure. It is possible by availability of various software and specialized programs. By using these software we can design a low weight reinforce structure which life is very good. These structures are more economical and safe by different forces acting on the building structure such as seismic load, snow load and wind pressure etc.

The current work examines the structural behavior of reinforced concrete columns, beam and footing in sloping geometry. In this study a $\mathrm{G}+8$ storey RCC building is analysed on varying sloping angles i.e., 0 o or plane surface, $10 \mathrm{o}$ and $15^{\circ}$.
\end{abstract}

The seismic forces and wind pressure are considered simultaneously as per IS: 1893-2002 and IS: 875 PART 3 respectively. The whole structure is analysis on software STAAD Pro v8i. The effect of sloping ground on building performance during earthquake and wind pressure is observed. Seismic analysis has been done using Linear Static method. Seismic analysis has been done using linear static method.

Keyword: sloping ground, STAAD Pro v8i., shear force, bending moment, axial force, shear force, seismic zone.

\section{INTRODUCTION}

Earthquakes occur when energy stored in elastically strained rocks is suddenly released. This arrival of vitality causes extreme ground shaking in the region close to the wellspring of the quake and sends wave of flexible vitality called seismic waves all through the earth. Most regular tremor are caused by sudden slippage along a blame zone. The flexible bounce back hypothesis proposes that if slippage along a blame is stuck to such an extent that versatile strain vitality develops in the twisting rocks on either side of the blame when the slippage occurs the vitality discharged causes a seismic tremor. At the point when a quake happens, the versatile vitality is discharged and conveys vibration that movements all through the earth. These vibrations are additionally called seismic waves. The investigation of how waves act in the earth is called seismology. The wellspring of a tremor is known as the Center, which is a correct area inside the earth were seismic waves are created by sudden arrival of put away flexible vitality. The epicenter is the point on the surface of the earth straightforwardly over the core interest.

\section{STAAD-pro V8i:-}

STAAD pro is the leading design and structural analysis software developed in Yorba Linda, CA by Research Engineers International. In the late months of year 2005, Research Engineers was brought by Bentley Systems. It is quite user friendly and supports a number of steel, timber and concrete design codes. It can make utilization of different manifestations of structural analysis from the conventional first order static analysis, second order p-delta investigation and geometrical non-linear analysis. These models can be used in different forms of dynamic analysis from model extraction and response spectrum to time history analysis.

STAAD.pro provides a very interactive user interface that allows users to draw frame sections and input 
load values and dimensions. According to specified specifications, it analyzes the structure and finally designs the members with reinforcement details for the RCC frame.

\section{Methods of Analysis:}

Analysis is performed on the basis of behaviour of the structure, external action, structural material and the type of selected structural model. Depending on the type of behaviour of the external verb and structure, the analysis can be further classified as given below.

\section{Equivalent static analysis:}

All designs against earthquake load should be considered on the dynamic nature of the load. However, for ordinary general structures, analysis by parallel linear analysis method is sufficient. This is allowed in most exercises for regular, low-rise buildings. Dynamic analysis is not included in this system; however, it is estimated to be responsible for the mobilization of the project. Firstly, the design base shear is calculated for the entire building, and then it is circulated with the height of the building. At each floor level, thus obtained, the lateral forces are distributed for different side load resistance elements.

(Duggal S.K., 2010)

\section{Nonlinear Static Analysis:}

This is a convenient method in which the analysis is done under permanent vertical load and it gradually increases the lateral load to estimate the pattern of distortion and damage to the structure. Nonlinear static investigation is the technique for seismic examination in which the structure is spoken to by the conduct bend, which demonstrates the connection between the base shear and the uprooting of the rooftop. It is otherwise called false examination.

\section{OBJECTIVES}

$>$ To analyse the building at three different sloping grounds (i.e., $0^{\circ}, 10^{\circ}$ and $15^{\circ}$ ).

$>$ To analyse these models condition in varying dead load, live load, seismic load and wind load.

$>$ To investigate the effect of sloping ground on structural displacement under seismic loading \& Wind pressure.

\section{METHOD OFANALYSIS}

A. For the static and dynamic analysis of multi-storey buildings have moment resisting frame

$>$ By STAAD Pro. software Method

$>$ Equivalent static lateral force method - For Static analysis only.

Response spectrum method - For Dynamic analysis only

The assumptions, formulations and limitations of the storey drift are discussed as per IS 1893(part-1):2002 for regular buildings only.

\section{RESULTS}

\section{Effect of sloping ground on beam forces}

The shear force and bending moment in plinth beams and ground storey beams compared to investigate the need of forces of sloping ground structures.

Table 6.3 Effect of sloping ground on critical forces in beams

\begin{tabular}{|c|c|c|c|c|c|c|}
\hline \multirow{4}{*}{$\begin{array}{l}\text { Force /Structural } \\
\text { component }\end{array}$} & \multirow{4}{*}{ Load case } & \multirow{2}{*}{\multicolumn{3}{|c|}{$\begin{array}{l}\text { Critical forces in beams } \\
\text { Ground slope (in degree) }\end{array}$}} & \multirow{3}{*}{\multicolumn{2}{|c|}{$\begin{array}{c}\text { Comparison of } \\
\text { various } \\
\text { analvses }\end{array}$}} \\
\hline & & & & & & \\
\hline & & \multirow{2}{*}{$\frac{0}{1}$} & \multirow{2}{*}{$\frac{10}{2}$} & \multirow{2}{*}{$\frac{15}{3}$} & & \\
\hline & & & & & $2 / 1$ & $3 / 1$ \\
\hline \multicolumn{7}{|c|}{ 1. Shear force Fy $(\mathrm{kN})$} \\
\hline a. Plinth level & EQX & 34.83 & 39.00 & 42.86 & 1.12 & 1.23 \\
\hline b. Ground storey & EQX & 55.06 & 49.65 & 49.43 & 0.90 & 0.90 \\
\hline c. Plinth level & EQZ & 64.13 & 43.01 & 56.76 & 0.67 & 0.89 \\
\hline d. Ground storey & EQZ & 65.80 & 49.44 & 51.25 & 0.75 & 0.78 \\
\hline \multicolumn{7}{|c|}{ 2. Bending moment $\mathrm{Mx}(\mathrm{kN}-\mathrm{m})$} \\
\hline a. Plinth level & EQX & 3597.72 & 446.44 & 4258.7 & 0.12 & 1.18 \\
\hline b. Ground storey & EQX & 7011.33 & 695.61 & 6410.2 & 0.10 & 0.91 \\
\hline \multicolumn{7}{|c|}{ 3. Bending moment $\mathrm{Mz}(\mathrm{kN}-\mathrm{m})$} \\
\hline a. Plinth level & EQZ & 377.72 & 571.56 & 549.48 & 1.51 & 1.45 \\
\hline b. Ground storey & EQZ & 690.33 & 696.56 & 753.14 & 1.01 & 1.09 \\
\hline Shear force Fy $(\mathrm{kN})$ & $1.5(\mathrm{DL}-\mathrm{EQZ})$ & 175.47 & 532.14 & 759.70 & 3.03 & 4.33 \\
\hline Bending moment $\mathrm{Mz}(\mathrm{kN}-\mathrm{m})$ & $1.5(\mathrm{DL}+\mathrm{EQZ})$ & 342.20 & 456.65 & 532.80 & 1.33 & 1.56 \\
\hline
\end{tabular}


Critical value of shear force Fy $(\mathrm{KN})$ and bending moment $\mathrm{Mz}(\mathrm{kN}-\mathrm{m})$ in beams decreases for different ground slopes.

From the shear, bending, torsional moment and displacements tables of eight-story reinforced concrete structures, built on plane ground and sloping ground under similar conditions, we can conclude that:

1. In short columns, because of their shorter height, a considerable increase in stiffness of their section is observed and the size of foundation is required more than plane surface.

2. While significant variation of several times of shear force and bending moment rise is indicated in sloping ground cases. Thus, the section of these columns is required to contain more steel to provide a greater resistance.

3. Moment force acting on long columns in sloping ground is more than shorter column and hence more steel is required.

Analysis and design of space building frame for seismic loading and wind pressure is very essential these days because construction of high rise buildings. It is also necessary to construct a economic and more durable structure. It is possible by availability of various software and specialized programs. By using these software we can design a low weight reinforce structure which life is very good. These structures are more economical and safe by different forces acting on the building structure such as seismic load, snow load and wind pressure etc.

Reinforced concrete (RC) frame buildings are most common type of constructions resting on plane and sloping ground (hilly area) in India. There buildings are subjected to several types of forces during their lifetime, such as static forces due to dead and live loads and dynamic forces due to the wind and earthquake.

Results from seismic analyses performed on three $\mathrm{RC}$ buildings with three different ground slopes $\left(0^{\circ}, 10^{\circ}\right.$, $15^{\circ}$ ) has been carried out by using static method. The top storey displacement and the footing reaction, axial force, shear and moment action induced in columns and beams have been studied to investigate the influence of sloping ground on structural performance of building frame.

\section{Effect of sloping ground on maximum displacement}

> Max. Displacement at top storey is not affected by increase in the various ground slopes, but it is affected and increases up to $5^{\text {th }}$ story and maximum displacement at ground storey increases by increase in the ground slopes under seismic load inX-direction and wind loading.

Max. Displacement at top storey is not affected by increase in the various ground slopes, and maximum displacement at ground storey is increases by increase in the various ground slopes under seismic load in Z-direction.

Wind pressure acting in $-X$ direction produce much horizontal pressure on building as the height increases above $15 \mathrm{~m}$.

The share force on Plinth beam increases as the slope of the ground increases and there are required much reinforcement and the size of beams is slit increases.

\section{CONCLUSION}

1. In short columns, because of their shorter height, a considerable increase in stiffness of their section is observed and the size of foundation is required more than plane surface.

2. While significant variation of several times of shear force and bending moment rise is indicated in sloping ground cases. Thus, the section of these columns is required to contain more steel to provide a greater resistance.

3. Moment force acting on long columns in sloping ground is more than shorter column and hence more steel is required.

\section{REFERENCE}

1. Agrawal P. and Shrikhande M. 2006, Earthquake resistant design of structures (Prentice-Hall of India Private Limited, New Delhi, India) Applied Technology Council (1996): Seismic Evaluation and Retrofit of Concrete Buildings, ATC-40, Vol.1.

2. Athanassiadou C. J, 2008, Seismic performance of $\mathrm{R} / \mathrm{C}$ plane frames irregular in elevation, Engineering Structures 30(2008):1250-1261.

3. Birajdar B. G. and Nalawade S. S. 2004. Seismic Analysis of Buildings Resting on Sloping Ground. In Thirteenth World Conference on Earthquake Engineering (13WCEE). Vancouver, Canada, Paper No.1472. 
4. Birajdar B. G., Nalawade. S. S., 13WCEE 2004 Seismic analysis of buildings resting on sloping ground. Conference on Our World in Concrete \& Structures: 29 - 30 August 2002, Singapore.
5. BIS. (2002). IS 1893 (Part 1) Indian Standard criteria for Earthquake Resistant Design of structures, Part1: General Provisions and buildings (Fifth Revision). New Delhi, Bureau of Indian Standards.

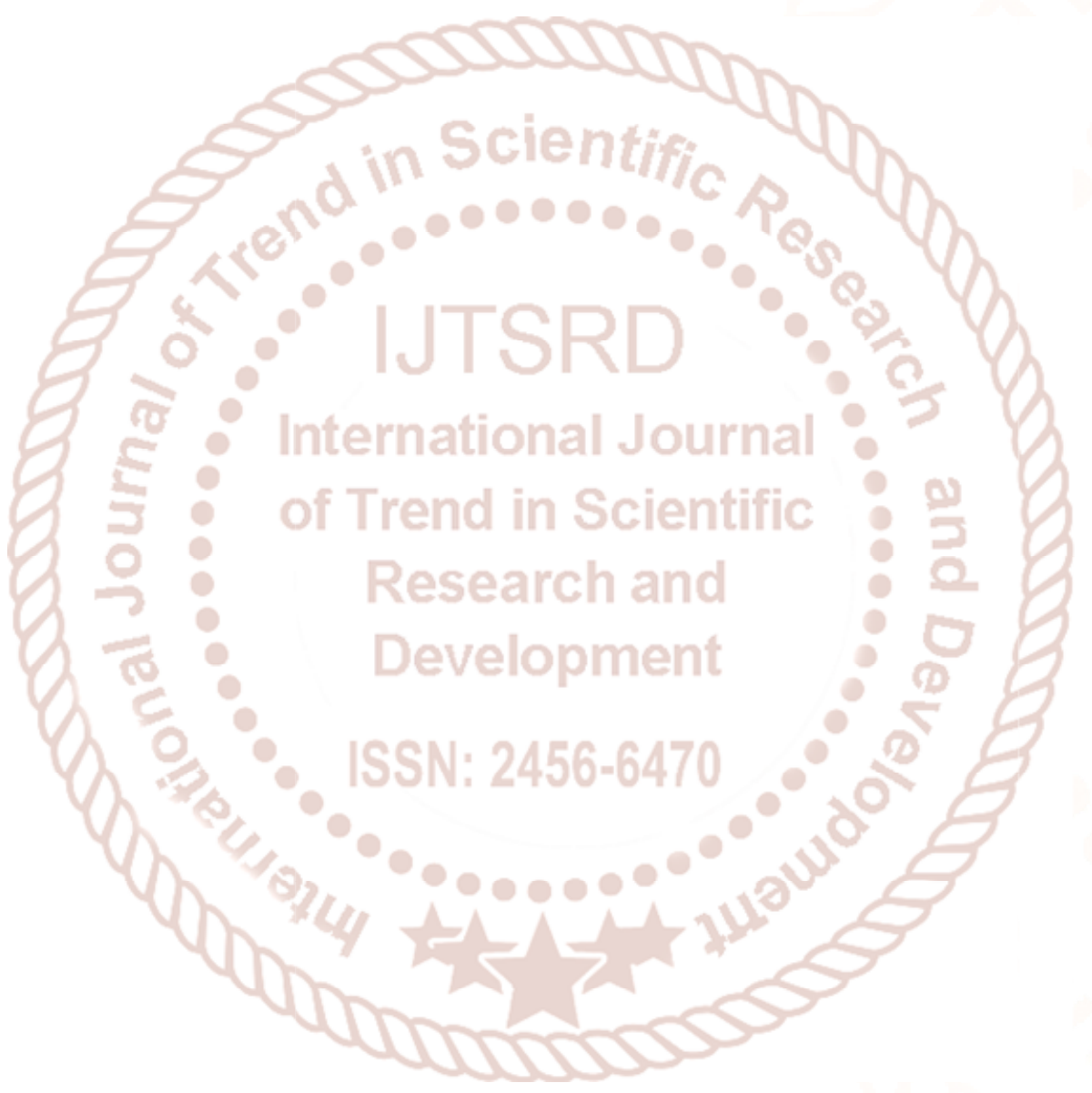

